\title{
ANALYSIS OF DIFFERENT INJURIES OF BASKETBALL PLAYERS BASED ON SURFACE ELECTROMYOGRAPHY
}

\author{
ANÁLISE DE DIFERENTES LESÕES EM JOGADORES DE BASQUETE COM BASE NA ELETROMIOGRAFIA \\ DESUPERFICIE
}

\author{
ANÁLISIS DE DIFERENTES LESIONES DE JUGADORES DE BALONCESTO BASADO EN \\ ELECTROMIOGRAFÍA SUPERFICIAL
}

\author{
Shanshan Lv' (ID \\ (Public Health Education) \\ Yanyu Dong ${ }^{2}$ (D) \\ (Public Sports) \\ 1. School of Physical Education, \\ China University of Mining and \\ Technology, Xuzhou, Jiangsu \\ 221116, China. \\ 2. Yanjing Medical College, Capital \\ Medical University, Beijing 100069, \\ China
}

\section{Correspondence:}

Xuzhou, Jiangsu 221116, China. ejsfeb553rb966@126.com fg466oyay639@126.com.

\begin{abstract}
Assessing the performance of basketball players is very important in the implementation of technical training programs. The application of electromyography (EMG) in basketball players is still relatively small. The evaluation of athletes' muscle state index by EMG can guide sports training. This study used surface electromyography to test and compare EMG data, analyze muscle discharge timing, contribution rate and integral EMG value of the turning movement, aiming to explore the prevention mechanism of different types of injury affecting basketball players. The synchronous measurement model of EMG signal and plantar pressure curve in jump shot process of basketball players is established to deepen coaches' understanding of jump shot movement rules and guide athletes to conduct scientific jump shot training. The research shows that the incidence of knee joint injury is relatively high in basketball players. Patella strain and softening, knee meniscus injury and cruciate ligament injury are the main types of injury, and there is no difference between genders.
\end{abstract}

Keywords: Electromyography; Basketball; Athletic Injuries.

\section{RESUMO}

A avaliação do desempenho dos jogadores de basqueteé muito importante na implementação de programas de treinamento técnico. A aplicação de eletromiografia (EMG) no basquetebol ainda é relativamente pequena. A avaliação do índice de estado muscular dos atletas por EMG pode guiar o treinamento esportivo. Este estudo utilizou a eletromiografia de superfície para testar e comparar os dados da EMG, analisar o tempo de descarga muscular, a taxa de contribuição e o valor integral da EMG do movimento de rotação, com o objetivo de explorar o mecanismo de prevenção de diferentes tipos de lesões entre jogadores de basquete. O modelo de medição síncrona do sinal EMG e da curva da pressão plantar no processo de arremessos por parte de jogadores de basquete é estabelecido para aprofundar a compreensão dos treinadores sobre as regras de arremessos e guiar atletas a realizar treinamentos de arremessos com bases científicas. A pesquisa mostra que a incidência de lesão nas articulações do joelho é relativamente alta entre os jogadores de basquete. Luxação e amolecimento de patela, lesão de menisco e lesão do ligamento cruzado são os principais tipos de lesão, e não há diferença entre generosos sexos masculino e feminino.

Descritores: Eletromiografia; Basquetebol; ; Traumatismos em Atletas.

\section{RESUMEN}

La evaluación del desempeño de los jugadores de baloncesto es muy importante en la implementación de programas de entrenamiento técnico. La aplicación de electromiografía (EMG) en el baloncesto aun es relativamente pequeña. La evaluación del índice de estado muscular de los atletas por EMG puede guiar el entrenamiento deportivo. Este estudio utilizó la electromiografía de superficie para testear y comparar los datos de la EMG, analizar el tiempo de descarga muscular, la tasa de contribución y el valor integral de la EMG del movimiento de rotación, con el objetivo de explorar el mecanismo de prevención de diferentes tipos de lesiones entre jugadores de baloncesto. El modelo de medición síncrona de la señal EMG y de la curva de la presión plantar en el proceso de lanzamientos por parte de jugadores de baloncesto es establecido para profundizar la comprensión de los entrenadores sobre las reglas de lanzamientos y guiar a los atletas a realizar entrenamientos de lanzamientos con bases científicas. La investigación muestra que la incidencia de lesión en las articulaciones de la rodilla es relativamente alta entre los jugadores de baloncesto. Luxación y ablandamiento de rótula, lesión de menisco y lesión del ligamento cruzado son los principales tipos de lesión, y no hay diferencia entre los sexos.

Descriptores: Electromiografía; Baloncesto; Traumatismos en Atletas 


\section{NTRODUCTION}

Fighting fiercely, requiring athletes to have a low center of gravity and keep their knees bent at any time are the remarkable characteristics of basketball nowadays. Only in this state can athletes effectively complete all kinds of actions on the court and complete the tactical and technical actions arranged by coaches (Hughes G, Dally N. 2015)[1]. At the same time, the knee joint has to bear a greater force, and sometimes the local part will suddenly be subjected to a greater impact force, especially when the knee joint is in a physiological and anatomical weakness. These huge impact forces will cause instantaneous damage to the knee joint or the strain of the adjacent structures around the knee joint (Wang Y J, Li J J, Zhou H J, et al. 2016) [2]. The mechanism of knee joint is very complex, and the treatment and recovery after injury is a big problem. Intuitive judgment refers to the non-logical judgment of athletes on the field (Jeffriess M D, Schultz A B, Mcgann T S, et al. 2015)[3]. Intuitive judgment in basketball refers to the non-logical judgment of basketball players on the changing field environment. Intuitive imagination refers to the direct supplement of the information of the stadium when the athletes have incomplete information on the field. The risk factors of anterior cruciate ligament injury are the basis for the development of targeted prevention programs, but the current mechanism of ACL injury is still controversial. For example, the risk factors of $A C L$ injury under different landing forms are not very clear (Afsharipour B, Sandhu M S, Rasool G, et al 2016)[4]. With the suddenness of the emergency stop, the rapid take-off increases the shot height to get rid of a defensive player's blocking method. Jump shots are a highly aggressive shooting method used in modern basketball games. The hit rate of the jumper determines the winning or losing of the team to a certain extent (Oliver J L, De S C M B A, Lloyd R S, et al. 2014)[5].

With the development of basketball, more attention is paid to the analysis and training of basketball technical movements. The use of turning movements is more and more extensive, and the utilization rate on the basketball court is also very high. It is not easy to detect and the attack is uncertain. The characteristics of sudden start. For example, dribbling turned to action, which became an important technical action for the dribble breakthrough, because with the improvement of basketball technology level, the defensive ability of the defensive players increased, the ball-breaking players need to use the body to protect the ball, the dribble can turn Effectively protect the ball. Analysis of the difference between basketball veterans and basketball novices in sports thinking is conducive to the teaching and training of basketball, helping beginner basketball players to learn from higher-level basketball players and helping them to mature faster. Especially for the selection of athletes, through the comparison of sports thinking, the specific laws affecting basketball players are clearly defined, which lays the foundation for scientific selection and avoids the blindness of selection. It facilitates the movement of the upper and lower legs and enables them to coordinate their movements. At the same time, the knee joints bear various forces from the thighs and lower legs, playing an excessive and supportive role. Knee joint is a load transfer station, which plays an important role in all aspects of the body activities. It is a double joint structure. These two joints are tibiofemoral joint and patellofemoral joint, respectively. At the same time, it bears a great responsibility to connect the two bone structures of the human body, so it bears a great deal of force.

\section{RELATED WORK}

Passing, dribbling, breaking and shooting in basketball will use turning movements. It has the characteristics of not easy to detect, offensive instability and sudden start. Turning means that the player takes one foot as the center foot, the front foot is the rotating shaft, and the other foot rotates the front foot. The upper body rotates with the movement of the moving foot, and the shoulder rotates with the waist to change the direction of rotation of the body. Farzaneh $E$ mentioned in the second edition of "Sports Training" that explosive power refers to the ability of muscles whose tension has begun to increase to overcome resistance at the fastest speed, and is a manifestation of rapid strength - German Earp J E research shows that explosive force is the ability of muscles that have begun to increase tension to further develop muscle strength at the fastest rate. Here he emphasizes that the fastest speed is closely related to explosive power, including the relationship with being included, and the fast power contains explosive power. In basketball, many technical movements are performed when the knee joint is in a weak physiological and anatomical position. At this time, the knee joint is the most vulnerable. Its injury mechanism is that the knee joint will cause contradictory movement of meniscus movement when it is stretched, which will cause the knee joint to receive injury. Long-term movement will wear the knee joint.

\section{ANALYSIS AND DISCUSSION}

In the process of completing the explosive front and back rotation, it is sure to involve the coordination work of each muscle, which can promote the integrity of the movement, compare and analyze the characteristics of myoelectric changes, and analyze the sequence of muscle mobilization. Muscle discharge timing. The part of the muscle integral EMG that is greater than $20 \%$ of the maximum is the active area. For better comparison, the data is normalized, the starting point of each action is zero seconds, and then the delay time is calculated backwards. As the number of shots increases, the EMG spectrum changes, indicating that the cerebral cortex begins to mobilize more muscle fibers to participate in the work. The results show that IEMG and RMS are significantly higher in fatigue state than in initial state, which indicates that more motor units must be recruited to work in order to maintain the work. As the changes of EMG recorded by surface electrodes are the total changes of discharges of various motor units, the total amount of discharges increases naturally. The amplitude of rectus femoris, gluteus maximus and erector spine muscles is the highest in the whole jump shot, and the amplitude of rectus abdominis is more obvious than that of rectus abdominis. Maintaining human balance after taking off mainly depends on the coordination of muscles. At this time, the discharges of muscles are relatively weakened. The amplitudes of erector spine muscle and rectus abdominis muscle are more obvious, and the contraction and discharge of rectus abdominis muscle are obvious when the body falls to the highest point.

It can be seen from Table 1 that the RMS peak of the rectus femoris muscle is the highest during the jumper of different positions, indicating that the rectus femoris is the main motive muscle of the jump shot. The motor unit of the rectus femoris during the jump shot was the highest. The coach should strengthen the training of the quadriceps and gluteus maximus during training to improve the height of the athlete's jump.

In the experiment, the volunteers sat with their feet flat on the floor, their upper arms horizontal on an adjustable table, their forearms vertical (see Figure 1), and their Elbows 90 degrees. The force sensor mounted on the wall is comfortable with a comfortable hand-sized ring and flexible steel pad and held on the participant's palm. The output of the force sensor is recorded on the acquisition system at the same time as that of the SEMG.

Table 1. RMS peak comparison results of athletes in different positions.

\begin{tabular}{c|c|c}
\hline Position & $\begin{array}{c}\text { Right peak of } \\
\text { rectus femoris }\end{array}$ & $\begin{array}{c}\text { Right peak of erector } \\
\text { spine muscle }\end{array}$ \\
\hline Forward & 256 & 249 \\
\hline Center-forward & 318 & 304 \\
\hline Guard & 298 & 287 \\
\hline
\end{tabular}




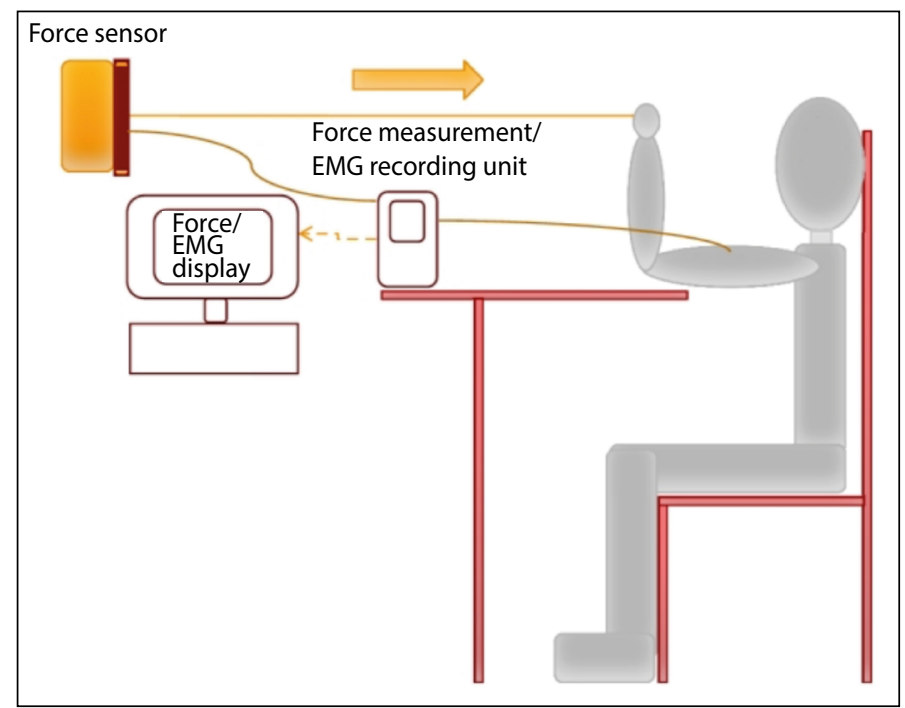

Figure 1. Experimental device simulation.

Assuming that the EMG signal generated by a motion unit is expressed as k, the EMG signal collected at the electrode after "superimposition synthesis" can be expressed as:

$C P V(k)=\sum_{j=1}^{k} \lambda_{j} / \sum_{j=1}^{m} \lambda_{j}$

Then the first moment of $k$ is:

$$
F_{i k}=\sum_{j=1}^{m} q_{j} x_{i j}
$$

The autocorrelation function of $\mathrm{M}$ is:

$$
f(t)=\sum_{j=1}^{N} \sum_{k \in Z} d_{k}^{j} \phi_{j k}(t)+\sum_{k \in Z} c_{k}^{N} \phi_{N k}(t)
$$

$T$ and $\mathrm{K}$ in the formula above generally take the same resistance $\mathrm{S}$, while $E$ can be used to configure the gain of the front-end circuit. Then the above formula can be resolved into:

$$
E_{m i}=\sum_{i=1}^{k}(i \Delta t) \cdot\left|S_{m i}\right|^{2}
$$

Then, the result of suppressing the common mode signal is sent to the post-stage differential amplifier for amplification, thereby calculating:

$\vec{E}=\frac{E_{m i}}{\sqrt{\sum_{i=1}^{k} E_{m i}}}$

In order to balance the differential amplifier, the amplification results are accurate, and the four resistors in E are laser-corrected. Equation (5) can be resolved into:

$$
U_{i j}=\frac{H_{i j}}{\sqrt{\sum_{t=1}^{k} H_{i t}^{2}}}, i=1, \ldots, n, j=1, \ldots, k
$$

The action potential waveform obtained from the above model is shown in Figure 2 below, which is basically consistent with the measured action potential curve.

The maximum instantaneous force of ACL occurs at the first peak moment of the horizontal and backward ground reaction force after landing. Based on the biomechanical model of ACL force, this study takes ACL force as dependent variable, and takes horizontal and backward ground reaction force, knee flexion angle, foot landing mode,

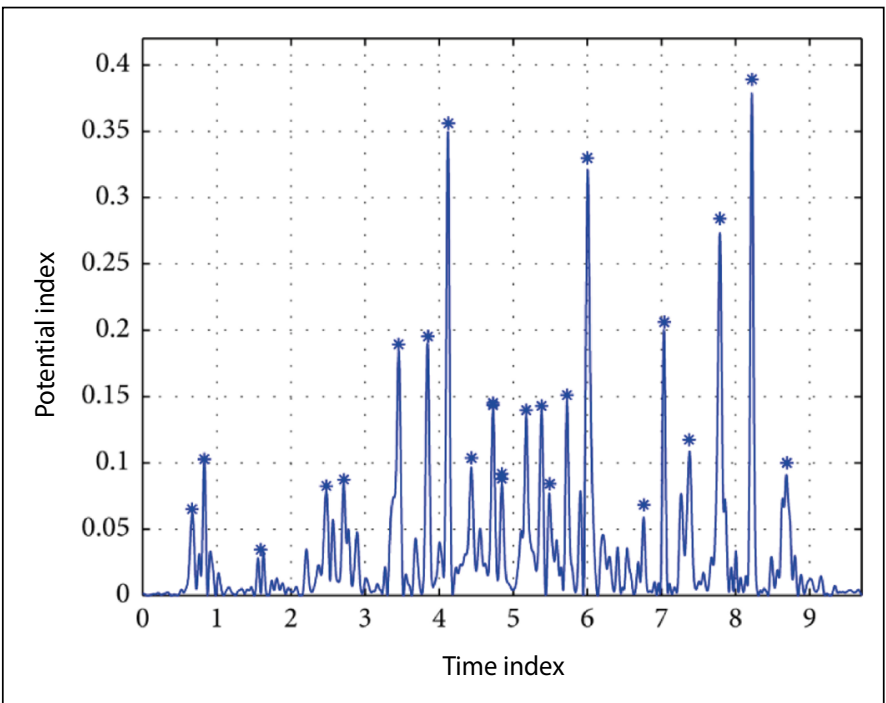

Figure 2. Action potential curve under mathematical model.

leg inclination angle, contraction force of femoral and gastrocnemius muscles, knee adduction and abduction moment and rotation moment as dependent variables.

EMG frequency domain analysis is based on the corresponding frequency of the maximum spectrum peak, which means that the discharge rate of a certain frequency (corresponding frequency) is the highest, so the peak of EMG power spectrum is the highest, but the corresponding frequency of the maximum spectrum peak is higher or lower, which indicates that the discharge rate of this frequency is the highest. In basketball matches, players from different positions assume different responsibilities and offensive and defensive tasks. Their body shape, psychology, technical structure and comprehensive ability will form certain special characteristics in the long-term training process. Further quantitative analysis of EMG activity is based on full-wave rectifier EMG. Integral electromyography (IEMG) is the sum of the area under the curve of the myoelectric signal after rectification and filtering, reflecting the amount of unit recruitment and the degree of synchronization of the muscle during exercise. The two-way analysis of variance of mixed design was used to determine the influence of gender and two types of landing forms on the biomechanical characteristics of lower limbs. Gender is an independent variable, and the landing form is a repeated variable. The software is used for statistical analysis. The significance criterion is defined as a type of error probability. More than 0.03 . For example, gender and landing forms have interactions between the lower limbs and the biomechanical parameters associated with $\mathrm{ACL}$ injury, and subsequent simple effects tests are performed.

\section{CONCLUSIONS}

The muscles that were first activated by the explosive front and rear turning movements were the right gluteus maximus and the left erector spinae. The left and right lateral rectus muscles and the right gastrocnemius muscle had the highest contribution rate. In the change of integral myoelectric value, there was a significant difference between the left gluteus maximus and the left rectus femoris, and there was a significant difference in the rectus abdominis. For basketball players, the right load makes the athlete's performance grow steadily. Therefore, the coaches should eliminate the fatigue of the athletes' training and competition in the training, speed up the recovery of the body, and even over-recover, use the physiological electromyography method to regulate the training and optimize the training process. In the process of jump shot, the contraction of abdominal and back muscles controls the balance of the body when the athletes jump to the highest point. At the same time, they coordinate with plantar reaction force to increase the stability of jump shot. It is very 
important to develop athletes'abdominal and dorsal muscle strength and improve their coordination ability for jump shot tactics, which should be paid attention to by coaches. When basketball players landed vertically, their legs inclined forward, the ground reaction force was larger, and the non-sagittal load was the reason for the increased risk of ACL injury. At the same time, the risk factors of ACL injury at the time of horizontal sudden landing are heel-to-ground, large horizontal backward ground reaction force and knee extension moment. For the abdominal muscle strength exercises which play a stabilizing role in turning movements, more weight-bearing training methods can be used.

\section{ACKNOWLEDGEMENTS}

2018 Capital Medical University Scientific Research and Cultivation Fund (Social Sciences) Project "Construction of Sports Risk Management and Control System in Colleges and Universities" (Project No. 2018PYS04); 2019 Capital Medical University Yanjing Medical College Scientific Research and Cultivation Project "University Sports risk prevention mechanism and countermeasures" (19QDKY12).

All authors declare no potential conflict of interest related to this article

AUTHORS' CONTRIBUTIONS: The author has completed the writing of the article or the critical review of its knowledge content. This paper can be used as the final draft of the manuscript. Every author has made an important contribution to this manuscript. Shanshan Lv, Yanyu Dong: writing and execution.

\section{REFERENCES}

1. Hughes $G$, Dally N. Gender difference in lower limb muscle activity during landing and rapid change of direction. Science \& Sports, 2015, 30(3):163-168.

2. Wang Y J, Li J J, Zhou H J, et al. Surface electromyography as a measure of trunk muscle activity in patients with spinal cord injury: a meta-analytic review. The Journal of Spinal Cord Medicine, 2016, 39(1):15-23.

3. Jeffriess M D, Schultz A B, Mcgann T S, et al. Effects of Preventative Ankle Taping on Planned
Change-of-Direction and Reactive Agility Performance and Ankle Muscle Activity in Basketballers. Journal of Sports Science \& Medicine, 2015, 14(4):864-876.

4. Afsharipour B, Sandhu MS, Rasool G, et al. Using surface electromyography to detect changes in innervation zones pattern after human cervical spinal cord injury. ConfProc IEEE Eng Med Biol Soc, 2016:3757-3760.

5. Oliver J L, De S C M B A, Lloyd RS, et al. Altered neuromuscular control of leg stiffness following soccer-specific exercise. European Journal of Applied Physiology, 2014, 114(11):2241-2249. 